\title{
The Influence of Coronavirus on the Profitability of Educational Enterprises
}

\author{
Qiancheng $\mathrm{Xu}^{1, *,{ }^{\dagger}}$ Linjia Zhang ${ }^{2,{ }^{\dagger}}$ Liuweier Zhang ${ }^{3, \dagger}$
}

\author{
${ }^{1}$ School of Arts \& Sciences and Simon Business School, University of Rochester, Rochester, NY 14627, America \\ ${ }^{2}$ Insurance School, Southwestern University of Finance and Economics, Chengdu 611130, China \\ ${ }^{3}$ Sydney Institute of Language and Commerce Business School, Shanghai University, Shanghai 266035, China \\ *Corresponding author. Email: guanghua.ren@gecacdemy.cn \\ These authors contributed equally.
}

\begin{abstract}
We use quarterly data, covering 4 years from 12/31/2016 to 12/31/2020, freely available from the CSMAR database. Data analysis is conducted by $\mathrm{R}$ and STATA statistical software. The one-way analysis of variance (ANOVA) and Kruskal (rank-sum) test is used to determine whether the mean values of three or more independent (unrelated) groups were statistically significant and to ensure that the observation of the hypothesis graph is accurate. We also use regression analysis to explore the epidemic's impact on the profitability of Chinese education enterprises. We analyze the profitability of enterprises by analyzing the return on total assets, return on common shareholders' equity and operating profit margin. The conclusion is that the COVID-19 epidemic has had a serious negative impact on listed companies in the education industry, leading to a significant decline in the profitability of enterprises in the education industry. By exploring the market reaction caused by the outbreak of COVID-19, the research on the loss of enterprise value under the impact of COVID-19 has been enriched. In particular, this paper focuses on the market response of educational companies, complementing research on the heterogeneous impact of COVID-19 on different industries.
\end{abstract}

Keywords: Profitability, COVID-19, Educational Enterprises.

\section{INTRODUCTION}

Broke out at the end of 2019, the coronavirus (COVID-19) has spread throughout the world, leading to more than 87 million confirmed infections and 1.88 million fatalities. The research reveals that the epidemic may lower China's economic growth in 2020 by $3.5 \%$ versus $4.4 \%$ for final consumption (relative to baseline). The service industry suffers the most from the outbreak, negatively impacting output reaching as high as $14.6 \%$. When moving to 2021, the hit to the economy shrinks to $2 \%(1.2-2.7 \%)$ [1]. The COVID-19 outbreak has had a profound impact on education worldwide. As a result of the closures of educational institutions, the impact on special education would likely be more detrimental since the special education population becomes more vulnerable in the aftermath of an outbreak [2]. During the COVID-19 outbreak, K12 (Kindergarten Through Twelfth Grade) education and training institutions underwent a major test. In March 2020, ISTUDY released a survey report on the epidemic's impact on K12 Education and Training Institutions, which pointed out that the COVID-19 epidemic has profoundly impacted the K12 education and training industry. $87 \%$ of institutions said that they had been greatly or even seriously affected by the COVID-19 epidemic. Among them, the three most influential factors are reduced revenue, high rental pressure and high labor costs. Sixty percent of institutions expect a Waterloo's first-half net revenue decline of more than 50 percent [3].

In order to contain the spread of novel Coronavirus, most countries have introduced stay-at-home orders requiring social distancing, which have had a devastating impact on all sectors of the economy [4, 5], particularly education, where online learning strategies have been introduced in order to avoid crowds gathering [6-8]. As a result of the COVID-19 pandemic, schools across the country are turning to distance teaching and learning. Teachers have had little time to adapt to this shift, which is a huge challenge for those who have not yet used some form of digital teaching platform. Students also have little time to adapt to online learning, which is a huge challenge due to the digital divide and 
other pressures caused by the pandemic [9]. In mid-February 2020, the Training and Education Professional Committee of China Association of Non-Government Education carried out an online questionnaire survey on "Novel Coronavirus Epidemic Impact on Training institutions" in 31 provinces and cities across the country. According to the survey, more than 90 percent of the training institutions believe that the epidemic will impact follow-up operations, and some institutions face serious difficulties in operation [10]. Therefore, taking the COVID-19 outbreak as an exogenous shock, we examine the market response of listed companies in China's education industry.

We use quarterly data, covering 4 years from $12 / 31 / 2016$ to $12 / 31 / 2020$, freely available from the CSMAR database. This database collects financial data on all public companies in China. It includes data on financial indicators reflecting the profitability of all educational companies in the Shanghai Stock Exchange and Shenzhen Stock Exchange from 12/31/2016 to $12 / 31 / 2020$.

Data analysis was conducted by $\mathrm{R}$ statistical software. The one-way analysis of variance (ANOVA) was used to determine whether the mean values of three or more independent (unrelated) groups were statistically significant. In addition, we used the Kruskal (rank-sum) test to ensure whether the observation of the hypothesis graph was not accurate. We also use regression analysis to explore the epidemic's impact on the profitability of Chinese education enterprises. We analyze the profitability of enterprises by analyzing the return on total assets, return on common shareholders' equity and operating profit margin. ROI is defined as net profit divided by average total assets. Return on common shareholders' equity is defined as net income divided by average net assets, and operating margin is defined as profit divided by revenue. Through these methods, we found that after the COVID-19 outbreak, the return on total assets of listed companies in the education sector fell by $6 \%$ compared with before the outbreak, the return on common equity of listed companies in the education sector is down $13.9 \%$ from pre-pandemic levels. The operating profit margin of listed companies in the education sector decreased by $27.6 \%$ compared with before the epidemic. The conclusion is that the empirical results of the study design provide strong empirical evidence for this paper that the COVID-19 epidemic has had a serious negative impact on listed companies in the education industry, leading to a significant decline in the profitability of enterprises in the education industry.

Compared with Anyang Wang's research on the market Development Strategy of education and training institutions [3]. Our research provides specific data and a precise calculation model to support our opinion, which is more objective and accurate than policy analysis and more easily used as a reference in the investment fields. Compared with Yuan Fei's article [11], our study about educational institutions in China before and after the epidemic is more macroscopic. Combined with Yuan Fei's accurate sampling survey, it is more convenient for the government to observe and macro-control the current situation of the education industry.

The remainder of the text is structured as follows. Section 2 introduces the dataset and the research method; Section 3 is empirical results and discussion, and Section 4 is the conclusion.

\section{DATA AND RESEARCH METHOD}

\subsection{Data Summary}

We use quarterly data, covering 4 years from $12 / 31 / 2016$ to $12 / 31 / 2020$, freely available from the CSMAR database. This database collects financial data on all public companies in China. The data includes data on financial indicators reflecting the profitability of all educational companies in the Shanghai Stock Exchange and Shenzhen Stock Exchange from 12/31/2016 to $12 / 31 / 2020$.

Table 1 reports the main variables and their descriptions. Table 2 reports the descriptive statistical results of the main variables in this paper, including the mean, standard deviation, minimum value and maximum value.

Table 1. Variables and descriptions.

\begin{tabular}{ll}
\hline Variable & Description \\
\hline Roa & Rate of return on total assets \\
Roe & Rate of return on common stockholders' equity \\
Pr & Operating profit rate \\
Post & Dummy variable, 1 if the date is after January 23,$2020 ;$ otherwise, 0 \\
Size & Enterprise size: the total assets of the enterprise are processed logarithmically \\
Leverage & The corporate leverage ratio, the total amount of debt divided by the total amount of \\
& assets \\
MB & Growth of the enterprise, the ratio of the total value of the enterprise to the total \\
& assets \\
\hline
\end{tabular}


Table 2. Descriptive Statistics.

\begin{tabular}{cc}
\hline Variable & Roa \\
Roe \\
Pr \\
Post \\
Size \\
Leverage \\
MB
\end{tabular}

\subsection{Methodology}

Data analysis was conducted by $\mathrm{R}$ statistical software. ANOVA is the main technique for analyzing data due to plenty of variables. The one-way analysis of variance (ANOVA) is used to determine any statistically significant differences between the means of three or more independent (unrelated) groups. ANOVA test is a statistical test used to determine the effect of two nominal explanatory variables on a continuous outcome variable. Within the ANOVA test, to make sure the data could fit the assumption, we use the log transformation of the data. All of the tests are doing in a 95\% confidence interval. Besides, we also use the Kruskal (rank-sum) test in the project to ensure that the assumption's observation of the graphs is not precise.

We also use regression analysis to explore the epidemic's impact on the profitability of Chinese education enterprises. Profitability usually refers to the ability of an enterprise to earn profits over a certain period. The size of profitability is a relative concept. That is, profit is relative to a certain amount of resource input. We analyze the profitability of enterprises by analyzing their rate of return on total assets, rate of return on common stockholders' equity and operating profit rate, where the rate of return on total assets is defined by net profit divided by average total assets, the rate of return on common stockholders' equity is defined by net profit divided by average net assets, operating profit rate is defined by profit divided by revenue.

We take these three indicators as dependent variables and before and after the epidemic as the independent variable. We also add the following control variables into the empirical model: the natural logarithm of the total market value of enterprises was taken to measure the size of enterprises, the ratio of total liabilities to total assets of enterprises, to measure the leverage ratio of enterprises and the ratio of total market value to total assets of enterprises, measuring the growth of enterprises.

We mainly used model (1) for regression estimation to explore the impact of COVID-19 on the profitability of enterprises in the education industry,

$$
\begin{gathered}
\text { Roa }_{i, t}=\alpha_{i}+\beta_{1} \text { Post }_{i, t}+\beta_{2} \text { Size }_{i, t}+ \\
\beta_{3} \text { Leverage }_{i, t}+\beta_{4} M B_{i, t}+\varepsilon_{i, t}
\end{gathered}
$$

\begin{tabular}{ccc} 
Std. Dev. & Min & Max \\
\hline 0.076 & -0.434 & 0.21 \\
0.297 & -1.068 & 1.087 \\
0.348 & -1.458 & 0.725 \\
0.488 & 0 & 1 \\
1.33 & 2.721 & 5.781 \\
31.619 & 0.071 & 84.023 \\
0.580 & 1.053 & 3.573 \\
Roe $_{i, t}=\alpha_{i}+\beta_{1}$ Post $_{i, t}+\beta_{2}$ Size $_{i, t}+$ \\
$\beta_{3}$ Leverage $_{i, t}+\beta_{4}$ MB $_{i, t}+\varepsilon_{i, t}$
\end{tabular}

$$
\begin{gathered}
\operatorname{Pr}_{i, t}=\alpha_{i}+\beta_{1} \text { Post }_{i, t}+\beta_{2} \text { Size }_{i, t}+ \\
\beta_{3} \text { Leverage }_{i, t}+\beta_{4} M B_{i, t}+\varepsilon_{i, t}
\end{gathered}
$$

in which $\operatorname{Roa}_{i, t}, \operatorname{Roe}_{i, t}$ and $\operatorname{Pr}_{i, t}$ are the rate of return on total assets, rate of return on common stockholders' equity and operating profit rate of the listed company $i$ in period $t$ individually, Post $_{i, t}$, Size $e_{i, t}$, Leverage $e_{i, t}$ and $M B_{i, t}$ are the dummy variable, size, leverage and growth of the enterprise $i$ in period $t$.

\section{EMPIRICAL RESULTS}

\subsection{ANOVA Test Results}

The response variable is Roa in the data, and the explanatory variable is 'year', representing the period. We used a 1 -way ANOVA test by setting $u_{0}$ equal to the means for Roa in every year are identical; $u_{l}$ equal to at least the mean of one group is different from others. We choose to use the log transformation for response variable Roa in this test since the original data has an unequal variance. Based on the output of the ANOVA table, the F-value is 3.9195, and the p-value is 0.004847 . Since the p-value is smaller than 0.05 , we have enough evidence to reject the null hypothesis and state that Roa's difference in each year. Therefore, Roa is affected by the virus. Kruskal test's p-value is $8.28 \mathrm{e}^{\wedge}-5$, which is the same result of 1-way ANOVA.

For the data Roe, we utilize the same method, and the p-value in ANOVA is 0.03579 , which is smaller than 0.05 . In the Kruskal-Wallis rank-sum test, the p-value is $5.978 \mathrm{e}^{\wedge} 5$ that could also reject the null hypothesis and prove that virus affects the Roe.

As for $P r$, the p-value in ANOVA is 0.47. However, based on the Shapiro and leven tests, we find out that it doesn't fit normality and equal variance; therefore, we use the result of the Kruskal test as the final evidence whose p-value is 0.0035 , which is smaller than 0.05 . that way, $\operatorname{Pr}$ is also associated with the virus. 


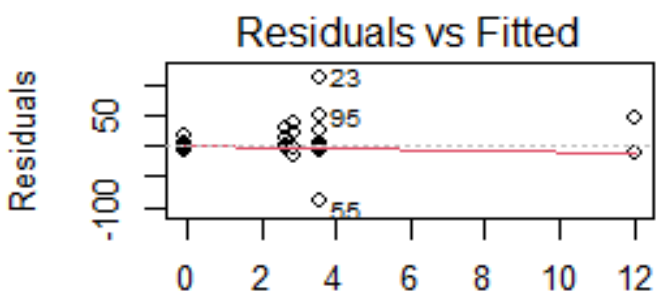

Fitted values

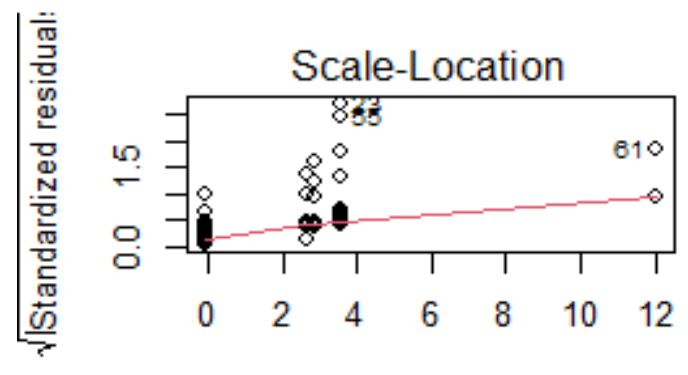

Fitted values

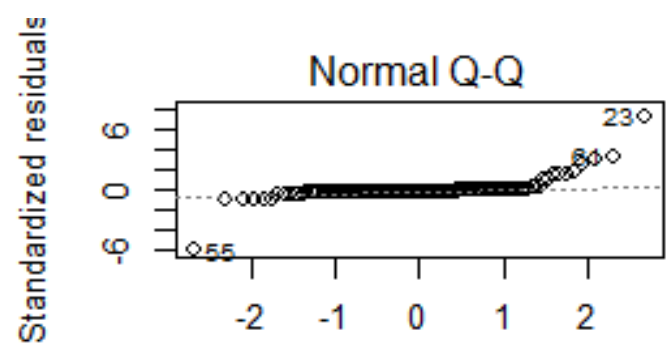

Theoretical Quantiles

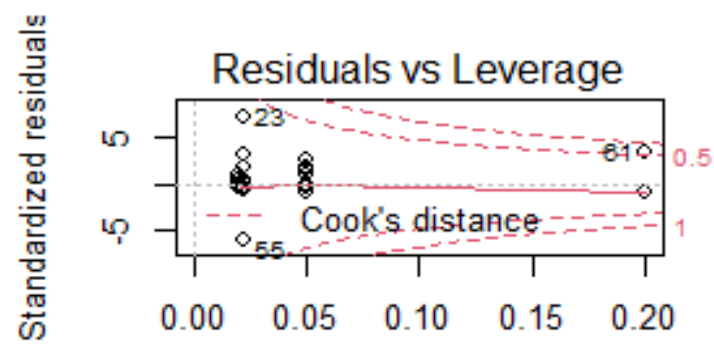

Leverage

Figure 1. Assumption test.

\subsection{The Influence of COVID-19 on the Rate of Return on Total Assets}

This section also presents regression results through the regression estimation model (1).

Table 3 reveals the impact of COVID-19 on the rate of return on total assets of listed companies in the education industry. The regression results showed that the regression coefficient of the Post variable was -0.05 and Significant at the $1 \%$ level, indicating that the rate of return on total assets of listed companies in the education industry decreased by 5\% after COVID-19 compared with before the outbreak. The rate of return on total assets is an indicator that reflects the comprehensive utilization effect of enterprise assets. The higher the rate of return on total assets is, the higher the utilization efficiency of the enterprise is, the stronger the enterprise's profitability is, and the higher the management level is.

\subsection{The Influence of COVID-19 on the Rate of Return on Common Stockholders' Equity}

Table 4 reveals the impact of COVID-19 on the rate of return on common stockholders' equity of public companies in the education industry. The regression results showed that the regression coefficient of the Post variable was -0.113 and significant at the $5 \%$ level, indicating that the rate of return on common stockholders' equity of public companies in the education industry decreased by $11.3 \%$ after the COVID-19 compared with before the outbreak. The rate of return on common stockholders' equity can reflect the ability of investors to obtain net income from their capital invested in an enterprise. That is, it reflects the relationship between investment and return. It is a core indicator to evaluate the level of return obtained from an enterprise's capital and its accumulation and reflects the comprehensive income from the capital operation of an enterprise. The higher the rate of return on common stockholders' equity of the enterprise is, the stronger the ability of the enterprise to obtain income from its capital, the better the operating efficiency is, and the higher the degree of protection for the investors and creditors of the enterprise is.

\subsection{The Influence of COVID-19 on the Operating Profit Rate}

Table 5 presents the impact of COVID-19 on the operating profit rate of public educational companies. The regression results showed that the regression coefficient of the Post variable was -0.238 and significant at the $1 \%$ level, indicating that the operating profit rate of public companies in the education industry decreased by $23.8 \%$ after the COVID-19 compared with before the outbreak. The operating profit rate reflects the profit brought to the enterprise by each dollar of net income, directly reflecting sales profitability. The larger this indicator, the higher the profit level of the enterprise's operating activities. 
Table 3. Linear regression result of Roa and Post.

\begin{tabular}{lcccccc}
\hline Roa & Coef. & St.Err. & t-value & p-value & $95 \%$ Conf & Interval \\
\hline Post & $-0.05^{* * *}$ & 0.017 & -2.94 & 0.004 & -0.083 & -0.016 \\
Size & $-0.024^{* *}$ & 0.011 & -2.13 & 0.036 & -0.046 & -0.002 \\
Leverage & -0.001 & 0 & -1.44 & 0.155 & -0.002 & 0 \\
MB & $0.031^{* *}$ & 0.014 & 2.17 & 0.033 & 0.002 & 0.059 \\
Constant & 0.084 & 0.063 & 1.33 & 0.187 & -0.041 & 0.209 \\
\hline Mean dependent var & 0.004 & & SD dependent var & 0.077 & \\
R-squared & 0.159 & Number of obs & & 0.009 & \\
F-test & 3.679 & Prob > F & -183.037 & \\
Akaike crit. (AIC) & -195.132 & Bayesian crit. (BIC) & & \\
\hline
\end{tabular}

Notes: $* * *$ means significant at $1 \%$ significance level, $* *$ means significant at $5 \%$ significance level, and $*$ means significant at $10 \%$ significance level.

Table 4. Linear regression result of Roe and Post.

\begin{tabular}{ccccccc}
\hline Roe & Coef. & St.Err. & t-value & p-value & 95\% Conf & Interval \\
\hline Post & $-0.113^{* *}$ & 0.06 & -2.32 & 0.023 & -0.258 & -0.02 \\
Size & -0.044 & 0.04 & -1.10 & 0.277 & -0.125 & 0.036 \\
Leverage & 0.002 & 0.002 & 1.05 & 0.298 & -0.002 & 0.005 \\
MB & 0.058 & 0.051 & 1.13 & 0.261 & -0.044 & 0.161 \\
Constant & 0.156 & 0.227 & 0.69 & 0.494 & -0.296 & 0.608 \\
\hline Mean dependent var & & 0.059 & SD dependent var & & 0.281 \\
R-squared & 0.224 & Number of obs & & \\
F-test & 5.615 & Prob > F & \multicolumn{2}{c}{0.001} & \\
Akaike crit. (AIC) & & 12.892 & Bayesian crit. (BIC) & \multicolumn{2}{c}{24.986} & \\
\hline
\end{tabular}

Notes: $* * *$ means significant at $1 \%$ significance level, ** means significant at $5 \%$ significance level, and $*$ means significant at $10 \%$ significance level.

Table 5. Linear regression result of $P r$ and Post.

\begin{tabular}{ccccccc}
\hline Pr & Coef. & St.Err. & t-value & p-value & $95 \%$ Conf & Interval \\
\hline Post & $-0.238^{* * *}$ & 0.079 & -3.02 & 0.003 & -0.395 & -0.081 \\
Size & 0.008 & 0.053 & 0.15 & 0.88 & -0.097 & 0.113 \\
Leverage & 0 & 0.002 & 0.21 & 0.836 & -0.004 & 0.005 \\
MB & 0.07 & 0.067 & 1.04 & 0.302 & -0.064 & 0.203 \\
Constant & -0.09 & 0.296 & -0.30 & 0.762 & -0.679 & 0.499 \\
\hline Mean dependent var & & 0.006 & SD dependent var & 0.356 & & \\
R-squared & & 0.127 & Number of obs & 83 & \\
F-test & 2.846 & Prob > F & 0.029 & \\
Akaike crit. (AIC) & & 61.652 & Bayesian crit. (BIC) & 73.746 & \\
\hline
\end{tabular}

Notes: $* * *$ means significant at $1 \%$ significance level, $* *$ means significant at $5 \%$ significance level, and $*$ means significant at $10 \%$ significance level.

\section{CONCLUSION}

The spread of COVID-19 in 2020 has increased uncertainties and downside risks for the Chinese economy. In the context of COVID-19, according to the deployment of the CPC Central Committee for epidemic prevention and control, the Ministry of Education has proposed that "any form of offline training and any form of gathering training activities are strictly prohibited during the epidemic period". The impact brought by the suspension of offline training and other factors caused by the epidemic makes all kinds of off-campus training institutions face severe survival challenges. To this end, this paper examines the impact of the COVID-19 outbreak on public educational companies in China by using the ANOVA test and the regression analysis method. The findings are as follows: the return on total assets of listed education companies decreased by $5 \%$, the return on common shares decreased by $11.3 \%$, and the operating profit margin of listed education companies decreased by $23.8 \%$ on average after the COVID-19 outbreak. In conclusion, the empirical results of the study design provide strong empirical evidence for this paper that the COVID-19 epidemic has had a serious negative impact on listed companies in the education industry, leading to a significant decline in the profitability of enterprises in the education industry.

Our research provides specific data and a precise calculation model to support our opinion, which is more objective and accurate than policy analysis and more easily used as a reference in the investment fields. Our study about educational institutions in China before and after the epidemic is more macroscopic. It is more convenient for the government to observe and macro-control the current situation of the education industry.

The specific reasons for the decline of profitability 
of listed companies in the education industry have not been fully explored, and we will conduct a more detailed analysis of them in future studies.

\section{REFERENCES}

[1] Duan, H., Bao, Q., Tian, K., et al, The hit of the novel coronavirus outbreak to China's economy, China Economic Review, 2021, vol. 67, 101606. DOI: https://doi.org/10.1016/j.chieco.2021.101606

[2] Yakut, A., Educators' experiences in special education institutions during the COVID-19 outbreak, Journal of Research in Special Educational Needs, 2021, forthcoming. DOI: https://doi.org/10.1111/1471-3802.12533

[3] Wang, A., Research on the market development strategy of K12 education and training institutions in the post-epidemic era- Take TAL as an example, China Market, 2021, issue. 23, pp. 94-96. DOI: https://doi.org/10.13939/j.cnki.zgsc.2021.23.094

[4] Fang, H., Wang, L., Yang, Y., Human mobility restrictions and the spread of the novel coronavirus ( 2019-nCoV ) in China, Journal of Public Economics, 2020, vol. 191, 104272. DOI: https://doi.org/10.3386/w26906

[5] Liu, S., Kong, G., Kong, D., Effects of COVID19 on air quality: human mobility, spillover effect and city connection, Environmental and Resource Economics, 2020, vol. 76, pp. 635-653. DOI: https://doi.org/10.1007/s10640-020-00492-3

[6] Gilead, T., Dishon, G., Rethinking future uncertainty in the shadow of COVID 19: Education, change, complexity and adaptability, Educational Philosophy and Theory, 2021, vol. 53, 1920395. DOI: https://doi.org/10.1080/00131857.2021.1920395

[7] Kawczak, S., Fernandez, A., Frampton, B., et al, Observations from transforming a continuing education programme in the COVID-19 era and preparing for the future, Journal of European CME, 2021, vol. 10, 1964315. DOI: https://doi.org/10.1080/21614083.2021.1964315

[8] Cahoon, A., Mcgill, S., Simms, V., Understanding home education in the context of COVID-19 lockdown, Irish Educational Studies, 2021, vol. 40, pp. 443-455. DOI: https://doi.org/10.1080/03323315.2021.1921010

[9] Bao, W., COVID-19 and online teaching in higher education: a case study of Peking University, Human Behavior and Emerging Technologies, 2020, vol. 2, pp. 113-115. DOI: https://doi.org/10.1002/hbe2.191
[10] Training education Committee of China Non-government Education Association, 80\% of training institutions affected by the epidemic look forward to the implementation of the policy to reduce the burden, research about after-school training and education industry during the epidemic period, 2020, pp. 78-80 https://kns.cnki.net/kcms/detail/detail.aspx?FileNa me $=$ ZKWM202004032 \&DbName $=$ CJFQ2020

[11] Yuan, F., Difficulties and solutions of post-epidemic education and training institutions: based on a survey in J City, Shandong Province, Business and Management, 2021, issue. 9, pp. 64-68.

https://doi.org/10.16517/j.cnki.cn12-1034/f.202105 11.002 